\title{
VNMKV Recommended Improved Farm Implements Adopted by the Farmers
}

\author{
Sanap J.G. ${ }^{1}$, kadam R.P ${ }^{2}$, Pawar G.S. ${ }^{3}$ \\ Department of Extension Education, College of Agriculture, Vasantrao Naik Marathwada Krishi Vidyapeeth Parbhani, \\ Maharashtra, India
}

\begin{abstract}
The study was conducted in purposively selected three talukas viz., Jintur, Parbhani and Purna of Parbhani District of Marathawada region of Maharashtra state during the year 2014-15. From each taluka, four villages selected purposively and from each village10 respondents were selected purposively, there by constituting a total sample size of 120 respondents. Data were collected by using personal interview method. The collected data were tabulated, analyzed and interpreted with the help of appropriate statistical tools. Majority of respondents were found having medium level of adoption of improved farm implements. It was observed that farming experience, social participation, extension contact, economic motivation and risk orientation had non-significant relationship with adoption of recommended improved farm implements whereas education, land holding, annual income and source of information had significant relationship with adoption of recommended improved farm implements by the respondents.
\end{abstract}

Keywords-Adoption, farm implements, farming experience, social participation, extension contact.

\section{INTRODUCTION}

Mechanization in agricultural embraces the use of tools, implements and machines for agricultural land development, crop production, harvesting and preparation for storage, storage, and on-farm processing. It includes three main power sources: human, animal, and mechanical. The manufacture, distribution, repair, maintenance, management and utilization of agricultural tools, implements and machines is covered under this discipline with regard as to how to supply mechanization inputs to the farmer in an efficient and effective manner. Improved farm implements and machinery are rightly called as inputs of input. It has been recognized as an integral part of agricultural development for improving resource use efficiency and productivity in agriculture. Improved farm implements are used for primary and secondary tillage operations, and harvesting of the crops, post harvest operations like threshing can also carried out with the help of improved farm implements and machinery. Improved farm implements perform field operations speedily, efficiently, uniformly and relieving the farmers from drudgery of the physical work.

The cropping systems like multiple and relay cropping can also possible with the help of improved farm implements. It means that, with proper use of improved farm implements farmers can produce more with minimum labour cost. Therefore, the present study "Adoption of Improved Farm Implements Recommended by Vasantrao Naik Marathwada Krishi Vidyapeeth" was planned with the following specific objectives

1) To study the profile of the respondents.

2) To study the adoption of improved farm implements by respondents.

3) To delineate relationship between profiles of the respondents with knowledge and adoption of improved farm implements.

\section{MATERIALS AND METHODS}

The present study was purposively undertaken in the three talukas viz., Jintur, Parbhani and Purna talukas of Parbhani district of Maharashtra state. Four villages were purposively selected from each taluka on the basis of higher number of respondents having farm implements. Thus, total twelve villages were purposively selected. From each selected village, 10 respondents were selected purposively by making a sample of 120 respondents. The present study was confined to ex-post-facto research design. The independent variables were measured by using suitable scales and procedures adopted by various researchers in past with due modification. The dependent variable taken up in this study was adoption of improved farm implements which was measured by developed structured schedule. An interview schedule was developed according to objectives of study and the data were collected by arranging personal interview with 120 respondents. The collected data were classified, 
tabulated and analyzed in order to make the findings meaningful.

III. RESULTS AND DISCUSSION

Socio-Personal characteristics of the farmers:

Table 1. Distribution of the respondents according socio personal characteristics. $(N=120)$

\begin{tabular}{|c|c|c|c|}
\hline Sr. No & Category & Frequency & Percentage \\
\hline \multicolumn{2}{|r|}{ Education (standard classification) } & & \\
\hline 1. & Illiterate & 13 & 10.84 \\
\hline 2. & Primary (1-4 std) & 27 & 22.50 \\
\hline 3. & Secondary (5-7 std) & 44 & 36.66 \\
\hline 4. & Higher secondary $(7-12 \mathrm{std})$ & 30 & 25.00 \\
\hline 5. & College level & 06 & 5.00 \\
\hline \multicolumn{2}{|c|}{ Land holding (As per Govt. of Maharashtra) } & & \\
\hline 1. & Marginal (up to 1 ha) & 13 & 10.83 \\
\hline 2. & Small (1.1 to $2 \mathrm{ha})$ & 41 & 34.17 \\
\hline 3. & Semi-medium (2.1 to 4 ha) & 47 & 39.17 \\
\hline 4. & Medium (4.1 to 10 ha) & 19 & 15.83 \\
\hline 5. & Large (10.1 ha and above) & 0 & 0.00 \\
\hline \multicolumn{2}{|r|}{ Annual income } & & \\
\hline 1. & Low( up to Rs.93638.59) & 12 & 10.00 \\
\hline 2. & Medium (Rs.93639-Rs.575111.39) & 86 & 71.67 \\
\hline 3. & High (Rs.575111.40 and above) & 22 & 18.33 \\
\hline & Mean: Rs 334377.00 \& SD: Rs 240736.00 & & \\
\hline \multicolumn{2}{|r|}{ Farming experience } & & \\
\hline 1. & Experience up to 9 years & 18 & 15.00 \\
\hline 2. & Experience in between $10-22$ years & 77 & 64.17 \\
\hline 3. & Experience above 23 years & 25 & 20.83 \\
\hline \multicolumn{2}{|r|}{ Mean: 15.76 yrs \& SD: 6.40 yrs } & & \\
\hline \multicolumn{2}{|r|}{ Social participation } & & \\
\hline 1. & Low (up to 2.46) & 16 & 13.34 \\
\hline 2. & Medium (2.47-4.14) & 94 & 78.33 \\
\hline 3. & High (4.15 and above) & 10 & 8.33 \\
\hline & Mean: 3.3 \& SD: 0.84 & & \\
\hline \multicolumn{2}{|r|}{ Extension contact } & & \\
\hline 1. & Low (up to 1.59) & 20 & 16.67 \\
\hline 2. & Medium (1.60-4.64) & 84 & 70.00 \\
\hline 3. & High (4.65 and above) & 16 & 13.33 \\
\hline & Mean: $3.12 \&$ SD: 1.52 & & \\
\hline \multicolumn{2}{|r|}{ Source of information } & & \\
\hline 1. & Low (up to 16.86) & 19 & 15.83 \\
\hline 2. & Medium (16.87-26.87) & 84 & 70.00 \\
\hline 3. & High (26.88 and above) & 17 & 14.17 \\
\hline & Mean: 21.84 \& SD: 5.00 & & \\
\hline
\end{tabular}

The personal, socio-economical, communicational, psychological and situational characteristics of the famers were studied and the data have been given in Table1.
Personal characteristics 


\begin{tabular}{|c|c|c|c|}
\hline \multicolumn{2}{|c|}{ Economic motivation } & & \\
\hline 1. & Low (up to 17.36) & 23 & 19.17 \\
\hline 2. & Medium (17.37-23.14) & 88 & 73.33 \\
\hline 3. & High (23.15 and above) & 9 & 7.50 \\
\hline & Mean: 20.85 \& SD: 2.89 & & \\
\hline \multicolumn{2}{|c|}{ Risk orientation } & & \\
\hline 1. & Low (up to 17.30) & 21 & 17.50 \\
\hline 2. & Medium (17.31-21.78) & 73 & 60.83 \\
\hline 3. & High (21.79 and above) & 26 & 21.67 \\
\hline & Mean: 19.55 \& SD: 2.24 & & \\
\hline
\end{tabular}

It was evident that more than one-third (36.66\%) of respondents were having secondary level of education followed by 25.00 per cent respondents in higher secondary level of education. Only 22.50 per cent respondents had education up to primary level whereas, 10.84 per cent respondents were illiterate and 5.00 per cent respondents had education up to college level. Most of the respondents $(39.17 \%)$ had semi- medium size of land followed by small (34.17\%), medium (15.83\%) and marginal (10.83\%). Whereas none of the respondents found in large land holding category. The majority $(71.67 \%)$ of the respondents had medium annual income, followed by 18.33 per cent and 10.00 per cent had high and low annual income, respectively. More than half of respondents (64 $17 . \%$ ) were having 9 to 22 years farming experience, whereas 20.83 per cent of the respondents were having farming experience of more than 23 years. While 50.00 per cent respondents were having farming experience less than 9 years. It was observed that most $(78.33 \%)$ of the Implement wise adoption of improved farm implements:

Table 2: Distribution of respondents according to implement wise adoption of improved farm implements recommended by

\begin{tabular}{|c|c|c|c|c|}
\hline \multicolumn{5}{|c|}{$V N M K V .(N=120)$} \\
\hline Sr No & Recommended implements & Frequency & Percentage & Rank \\
\hline $\mathrm{I}$ & \multicolumn{4}{|c|}{ Man operated implements } \\
\hline 1 & Cotton uprooting hipe & 86 & 71.66 & I \\
\hline 2 & Ransawadi & 46 & 38.33 & II \\
\hline 3 & Sugarcane knife & 45 & 37.50 & III \\
\hline 4 & Paddy threshing machine & 40 & 33.33 & IV \\
\hline 5 & MKV hand hoe & 24 & 20.00 & $\mathrm{~V}$ \\
\hline 6 & Seed treatment drum & 17 & 14.16 & VI \\
\hline 7 & MKV sickle & 16 & 13.33 & VII \\
\hline 8 & Gunny bag filling machine & 04 & 3.33 & VIII \\
\hline 9 & Bhendi plucker & 00 & 00 & - \\
\hline 10 & Fruit cutting machine & 00 & 00 & - \\
\hline 11 & Maize shelling machine & 00 & 00 & - \\
\hline
\end{tabular}
followed by 13.34 per cent of the respondents having low level of social participation and 8.33 per cent of them had high social participation. As far as extension contact of the respondents was concerned, 70.00 per cent of them had medium extension contact followed by 16.67 per cent having low extension contact and only 13.33 per cent farmers were having high extension contact. Majority of the respondents $(70.00 \%)$ had medium level of utilization of sources of information, about 15.83 per cent of the respondents having low level of utilization of sources of information followed by 14.17 per cent of the respondents having high level of sources of information. It was noticed that most $(73.33 \%)$ of the respondents had medium economic motivation followed by low $(19.17 \%)$ economic motivation and high $(7.50 \%)$ economic motivation. It was observed that half of the $(60.83 \%)$ respondents had medium level of risk orientation followed by high $(21.67$ $\%)$ and low (17.50\%) risk orientation. 


\begin{tabular}{|c|c|c|c|c|}
\hline 12 & Rotary maize shelling machine & 00 & 00 & - \\
\hline 13 & Nalikadar maize shelling machine & 00 & 00 & - \\
\hline 14 & Biba breaking machine & 00 & 00 & - \\
\hline 15 & MKV dibbling machine & 00 & 00 & - \\
\hline 16 & Bamboo machine & 00 & 00 & - \\
\hline 17 & Seed and fertilizer spreading machine & 00 & 00 & - \\
\hline 18 & Peg breaking machine & 00 & 00 & - \\
\hline 19 & Sunflower threshing machine & 00 & 00 & - \\
\hline II & \multicolumn{4}{|c|}{ Bullock drawn improved farm implements } \\
\hline 1 & MKV tifan & 82 & 68.33 & $\mathrm{I}$ \\
\hline 2 & Bullock drawn seed and fertilizer tifan & 75 & 62.50 & II \\
\hline 3 & Sara yantra & 74 & 61.66 & III \\
\hline 4 & Groundnut digging machine & 60 & 50.00 & IV \\
\hline 5 & One row sowing machine & 48 & 40.00 & $\mathrm{~V}$ \\
\hline III & \multicolumn{4}{|c|}{ Tractor drawn farm implements } \\
\hline 1 & Rotavater and plough & 98 & 81.66 & $\mathrm{I}$ \\
\hline 2 & Banding machine & 46 & 38.33 & II \\
\hline 3 & Spraying machine & 00 & 00.00 & - \\
\hline IV & \multicolumn{4}{|c|}{ Other university developed but VNMKV recommended implements } \\
\hline 1 & Knapsac spraying machine & 118 & 98.33 & $\mathrm{I}$ \\
\hline 2 & Ridger & 55 & 45.83 & II \\
\hline 3 & Electrical threshing machine & 35 & 29.16 & III \\
\hline 4 & Rotavator & 20 & 16.66 & IV \\
\hline 5 & Multipurpose sowing machine & 0 & 00.00 & - \\
\hline $\mathrm{V}$ & \multicolumn{4}{|c|}{ Traditional farm implement } \\
\hline 1 & Bullock cart & 114 & 95.00 & $\mathrm{I}$ \\
\hline 2 & Deshi harrow & 112 & 93.33 & II \\
\hline 3 & Deshi iron plough and wooden tifan & 110 & 91.66 & III \\
\hline 4 & Wooden hoe & 96 & 80.00 & IV \\
\hline 5 & Wooden plough & 90 & 75.00 & $\mathrm{~V}$ \\
\hline 6 & Keni & 62 & 51.66 & VI \\
\hline
\end{tabular}

The table 2 indicates that implement wise adoption of improved farm implements

i) Man operated improved farm implements: The cotton uprooting hipe is adopted by most of the respondents in per cent 71.66 per cent which ranks first. The Ransawdi, sugarcane knife, paddy threshing machine were adopted by respondents in per cent 38.33, 37.50, 33.33 per cent respectively. Hand hoe, seed treatment drum, MKV sickle, gunny bag filling machine are having very less adoption in per cent 20.00, 14.16, 13.33, 3.33 per cent respectively. Other remaining improved farm implements were not adopted by respondents such as bhendi plucker, fruit cutting machine, maize shelling machine, rotary maize shelling machine, nalikadar maize shelling machine, biba breaking machine, MKV dibbling machine, bamboo machine, seed and fertilizer spreading machine, peg breaking machine, sunflower threshing machine.

Cotton uprooting hipe was adopted by most of the farmers because it is convenient and time saving. Other implements adopted very less may be due to inadequate knowledge about man operated improved farm implements. And also man operated implements more time and labours are required, due to which there was less adoption observed.

ii) Bullock drown improved farm implements: The majority $(68.33 \%)$ of the respondents had adoption of MKV tifan which ranks first, followed by bullock drawn 
seed and fertilizer tifan i.e. 62.50 per cent which ranks second. Sara yantra is having adoption about 61.66 per cent which ranks third, followed by groundnut digging machine i.e. 50.00 per cent. One row sowing machine is having very less adoption i.e. 40.00 per cent.

Indian farmers are still not ready for mechanized farming due to low economic condition and small land holding, so they make full use of bullock drawn implements. They are also economical affordable to them.

iii) Tractor drawn farm implements: In tractor drawn implements majority of respondents i.e. 81.66 per cent had adopted rotavator and plough which ranks first, while 38.33 per cent had adopted band forming machine. Whereas, none of the respondent adopted tractor drawn spraying machine.

For preparatory tillage operation adoption of rotavator and plough was high, because it is easy to operate, cost saving, time saving. Land holding of farmers was medium and cost of tractor drawn spraying machine is high, due to that non adoption of tractor drawn spraying machine.

iv) Other university developed but VNMKV recommended implements: The table 2 indicates that majority of respondents 98.33 per cent adopted knapsack spraying machine which ranks first, while 45.83 per cent had adopted ridger which ranks second. The electric threshing machine and rotavator had very less adoption i.e. 29.16 and 16.66 per cent respectively. None of the respondent adopted multipurpose sowing machine.

Knapsack sprayer was adopted by considerable number of farmers because it is very easy to use economically affordable to the farmers.

v) Traditional Farming implements: Majority (95.00\%) of the respondents are having bullock cart which ranks first, 93.33 per cent had adoption of deshi harrow which ranks second, while deshi iron plough and wooden tifan had equal adoption i.e. 91.66 per cent. Eighty per cent of the respondents adopted wooden hoe while wooden plough by 75.00 per cent and keni is adopted by 51.66 per cent respondents respectively.

Due to medium size of land holding and annual income farmers cannot afford improved farm implements and they don't go for mechanized farming. It is also not economical to purchase improved farm implements for limited size of land. Thus most of the farmers are still using traditional implements.

The above findings were similar with the findings of Salunkhe (1994), Jalak (2002), Mahanavar (2013) and Nagraj et al. (2013).

Extent of overall adoption of improved farm implements
Table 3: Distribution of the respondent according to their extent of adoption of farm implements $(n=120)$

\begin{tabular}{|c|c|c|c|}
\hline $\begin{array}{l}\text { Sr. } \\
\text { No }\end{array}$ & Category & Frequency & Percentage \\
\hline 1 & $\begin{array}{c}\text { Low (up to } \\
13.20 \text { ) }\end{array}$ & 22 & 18.33 \\
\hline 2 & $\begin{array}{c}\text { Medium } \\
\text { (13.21 to } \\
24.10)\end{array}$ & 80 & 66.67 \\
\hline \multirow[t]{2}{*}{3} & $\begin{array}{c}\text { High } \\
(24.11 \text { and } \\
\text { above })\end{array}$ & 18 & 15.00 \\
\hline & Total & 120 & 100.00 \\
\hline \multicolumn{2}{|c|}{ Mean=18.16 } & & $\mathrm{SD}=5.45$ \\
\hline
\end{tabular}

Table 3 indicates that more than half of the $(66.67 \%)$ respondents had medium level of adoption, while (15.00\%) had high and only 18.33 per cent had low level of adoption of farm implements.

Majority of respondent adoption level was medium, may be due to medium education, medium land holding, medium annual income and medium knowledge. The similar results were observed by Akshaya Ghintala, Kishan Singh (2013).

Coefficient of correlation between profiles of respondents with adoption of recommended improved farm implements

Table 4. Relationship of profile of respondents with adoption of recommended improved farm implements

\begin{tabular}{|c|c|c|}
\hline $\begin{array}{c}\text { Sr. } \\
\text { No }\end{array}$ & $\begin{array}{c}\text { Independent } \\
\text { variables }\end{array}$ & Adoption(' $r$ ' value) \\
\hline 1. & Education & $0.2658^{* *}$ \\
\hline 2. & Land holding & $0.4902^{* *}$ \\
\hline 3. & Annual income & $0.4811^{* *}$ \\
\hline 4. & Farming experience & $-0.0312^{\mathrm{NS}}$ \\
\hline 5. & Social participation & $0.1721^{\mathrm{NS}}$ \\
\hline 6. & Extension contact & $0.1776^{\mathrm{NS}}$ \\
\hline 7. & $\begin{array}{c}\text { Sources of } \\
\text { information }\end{array}$ & $0.4606^{* *}$ \\
\hline 8. & $\begin{array}{c}\text { Economic } \\
\text { motivation }\end{array}$ & $0.1809^{\mathrm{NS}}$ \\
\hline 9. & Risk orientation & $0.1567^{\mathrm{NS}}$ \\
\hline
\end{tabular}

NS: Non significant

**: Significant at 0.01 per cent level

It was observed from table 4 that farming experience; social participation, extension contact, economic motivation and risk orientation had non-significant relationship with 
adoption of recommended improved farm implement of the respondents. Whereas education, land holding, annual income and source of information had significant relationship with adoption of recommended improved farm implement by the respondents. It indicates that the farmers having more education helps to increase knowledge and also increases their adoption of improved farm implements. Land holding is more farmers are interested to purchase improved farm implements for cultivation of land. Higher annual income leads to high investment on farming for use of cost intensive technologies and thus increases knowledge. More use source of information farmers get more knowledge about improved farm implements, he also came to know benefits of farm implements and thus adoption of improved farm implements recommended by Vasantrao Naik Marathwada Krishi Vidyapeeth increase. The similar results were observed by Ambavane (2014), Sawale (2011), Atar (2012), Lad (2013) and Shinde (2014).

\section{CONCLUSIONS}

The majority of the respondents having secondary and higher secondary education, semi medium size of land holding, having annual income between Rs. 93639 to Rs. 575111.39, having farming experience between 10-22 years, medium social participation, extension contact, source of information, economic motivation and risk orientation respectively. University has developed number of implements but traditional farm implements are more adopted by the farmers followed by bullock drawn farm implements developed by VNMKV, Parbhani. Majority of the respondents were found to have medium level of adoption of farm implements. It was observed that farming experience, social participation, extension contact, economic motivation and risk orientation had nonsignificant relationship with adoption of recommended improved farm implement of the respondents whereas education, land holding, annual income and source of information had significant relationship with adoption of recommended improved farm implement by the respondents.

Therefore it is suggested that the State Dept of Agril., SAUs, extension agencies should motivate the farmers for better participation in exhibition, krishi meala etc along with that they must trained by organizing group discussion and by organizing training programme on improved agricultural implements. It helps for increasing adoption of improved farm implement by the respondents.

\section{REFERENCES}

[1] Ambavane, D.N. 2014. Knowledge and adoption of recommended chilli production technology by the growers. M. Sc. (Agri.) Thesis, submitted to VNMKV, Parbhani.

[2] Attar, R.S. 2012. Study on knowledge and adoption of recommended grape cultivation practices by the grape growers, M.Sc. (Agri.), Thesis, submitted to MKV, Parbhani (M.S.).

[3] Ghintala, A and Singh, K. 2013. Knowledge and adoption of sprinkler irrigation system by the farmers of Banaskantha district of north Gujarat. Indian Journal Extension Education and Rural Development. 21: $26-29$.

[4] Jalak, D.V. 2002. A study of knowledge and adoption of improved farm implements evolved by MPKV, Rahuri, M.Sc. (Agri.) Thesis, submitted to MPKV, Rahuri, (MS).

[5] Lad, A.S. 2013. Knowledge and adoption of recommended package of practices of green gram. M.Sc. (Agri.) Thesis, VNMKV, Parbhani (M.S.).

[6] Mahanavar, D.V. 2013. Knowledge and adoption of improved farm implements developed by Vasantrao Naik Marathwada Krishi Vidyapeeth. M.Sc. (Agri.) Thesis, submitted to VNMKV, Parbhani.

[7] Nagraj, P.S., Dhananjaya Swamy, Madhushree, A and Vidyadhara, B. 2013. A study on knowledge and adoption of farm mechanization by paddy grower in Tungabhadra project area, Karnataka. International Journal of agriculture and food science technology. 4(4): 385-390.

[8] Salunkhe, D.C. 1994. A study of farm implement utilization behaviour of fanners from Sangamner tahsil of Ahmednagar district. M.Sc. (Agri.) Thesis, submitted to MPKV, Rahuri, (MS), India.

[9] Sawale, S.V. 2011. Knowledge and adoption of post harvest technology by the pomegranate growers M.Sc. (Agri.) Thesis, submitted to MKV, Parbhani. 